Рекомендована д. фрармац. наук, проф. С. О. Васюк

УДК 615.214.3.099.074

DOI 10.11603/2312-0967.2016.3.6816

\title{
ВИЗНАЧЕННЯ СЕРТИНДОЛУ В КРОВІ МЕТОДОМ ФЛУОРЕСЦЕНТНОЇ СПЕКТРОСКОПIї
}

\author{
(c) С. І. Давидович ${ }^{1}$, І. Й. Галькевич ${ }^{1}$, О. В. Шамлян ${ }^{2}$ \\ Львівський національний медичний університет імені Данила Галицького ${ }^{1}$ \\ Центральна науково-дослідна лабораторія та лабораторія промислової \\ токсикології ${ }^{2}$ Львів
}

\begin{abstract}
Резюме: незважаючи на прогрес у лікуванні психічних захворювань, лікування таким сучасним антипсихотичним засобом, як сертиндол досі асоціюється з токсичними і летальними наслідками. У статті наведено результати визначення сертиндолу в крові, використовуючи фрлуоресціюючі властивості даного препарату. У $96 \%$ етанолі спектр фрлуоресценції сертиндолу характеризується збудженням молекули при 310 нм і емісією при 345 нм. В екстрактах із крові було визначено до 87 \% сертиндолу. Межа кількісного визначення сертиндолу в крові становить 12 нг / мл при відносній похибці 2,41\%.
\end{abstract}

Ключові слова: сертиндол, кров, срлуоресценція, ізолювання.

Вступ. Антипсихотичні лікарські засоби широко призначають для лікування шизофренії та психозів. Одним 3 таких препаратів є сертиндол. Дані постмаркетингових досліджень із фрармаконагляду цього препарату та аналіз джерел літератури виявили дозозалежний ризик виникнення аритмії та раптової кардіогенної смерті при його прийомі [3, 5]. У зв'язку з повідомленнями про інтоксикації сертиндолом, розробка експресних методів виявлення та визначення його у крові постраждалого $є$ актуальним завданням при проведенні лабораторних та токсикологічних досліджень [6].

Згідно з оглядом літератури, для визначення кількісного вмісту препарату в біологічних рідинах найчастіше використовують високоефективну рідинну хроматографрію $[1,2]$. Проте метод фрлуоресцентної спектрометрії також дозволяє визначати сертиндол на рівні концентрацій, що виражаються в нг/мл. В літературі описано методики фрлуоресцентного визначення сертиндолу в лікарських фрормах, проте не описано визначення даного препарату в біологічних рідинах цим методом [4].

Мета роботи - розробка чутливої експресної методики визначення сертиндолу в крові на основі його флуоресціюючих властивостей.

Методи дослідження. Інтенсивність фрлуоресценції розчинів сертиндолу вимірювали на спектрофлуориметрі марки Hitachi MPF4 (Японія), оснащеного ксеноновою лампою. Спектри фрлуоресценції знімали при ширині щілини монохроматора 5 нм, швидкість сканування 30 нм/хв, l=1 см. Довжину хвилі збудження і випромінювання встановлювали на основі аналізу спектрів.
Для виготовлення серії стандартних розчинів використовували сертиндол, отриманий 3 SigmaAldrich, кваліфрікації HPLC, із вмістом діючої речовини 99,98 \%. Із відповідної наважки готували розчин сертиндолу в 96 \% етанолі 3 концентрацією 1 мг/мл (розчин А).

Вивчали залежність спектрів фрлуоресценції сертиндолу в різних органічних розчинниках - $96 \%$ етанолі, ізопропанолі та ацетонітрилі. Концентрація сертиндолу в кожному з них становила 10 мкг/мл (Ч=0,3).

Шляхом розведення розчину А 96 \% етанолом готували серію стандартних розчинів із концентрацією $10,50,100,250,500,1000$ нг/мл (n=3 для кожного вмісту препарату). Інтенсивність фрлуоресценції вимірювали при 345 нм ( $\lambda_{36}=310$ нм, чутливість 3).

Методика ізолювання сертиндолу з крові. Готували модельні суміші сертиндолу з кров'ю, яку одержували у Львівському обласному центрі служби крові та зберігали при $-20{ }^{\circ} \mathrm{C}$. Кров перевіряли на відсутність лікарських засобів. Для виготовлення модельних зразків до 5 мл крові вносили по 0,05; 0,25; 0,5; 1,25; 2,5; 5,0 мкг сертиндолу та вносили по 5 мл води.

Проби струшували 2 хв до отримання гомогенної маси. В досліджувані зразки вносили по 5 мл $20 \%$ розчину оксалатної кислоти і проби 20 хв обробляли ультразвуком (частота 52кГц). Після цього проби центрифугували (10000 об/хв, 15 хв). Центрифугати відокремлювали, а залишок повторно обробляли 2 мл 20 \% розчину оксалатної кислоти, після чого рідину відокремлювали центрифругуванням.

Центрифругати об'єднували та доводили 30 \% розчином натрію гідроксиду до рН 11 (за універсальним індикатором). Двічі екстрагували сертиндол 1,2-дих-

ISSN 2312-0967. Фармацевтичний часопис. 2016. № 3 
лоретаном (порціями по 7 мл). Для екстракції застосовували 1,2-дихлоретан кваліфікації х. ч. Дихлоретанові витяжки об'єднували, випаровували розчинник досуха при $40{ }^{\circ} \mathrm{C}$. Сухий залишок кількісно розчиняли в 5 мл 96 \% етанолу і ці розчини використовували для визначення сертиндолу фрлуориметричним методом.

Результати й обговорення. На рисунку 1 наведено спектри орлуоресценції сертиндолу залежно від природи розчинника. В ізопропанольних розчинах інтенсивність флуоресценції $€$ дещо вищою, проте при дослідженні контрольних проб із крові більшою мірою спостерігався матричний ефрект, в результаті чого значно зменшувалась чутливість. Для визна- чення вмісту сертиндолу доцільно використовувати етанольні розчини. В цьому розчиннику для сертиндолу $\lambda_{36}=310$ нм, а $\lambda_{\text {ем. }}$ спостерігається при 340 нм. При знятті спектрів срлуоресценції контрольних проб із крові при даних довжинах хвиль не спостерігалось фрлуоресценції.

У межах концентрацій сертиндолу від 10 нг/мл до 1000 нг/мл градуювальний грасрік (рис. 2) описується залежністю $Y=2,88+0,296 \times X$, де $Y$ - інтенсивність фрлуоресценції, а $X$ - концентрація сертиндолу в розчині (нг/мл). Відносна похибка кількісного визначення сертиндолу в $96 \%$ етанолі становить 0,98\%. Межа виявлення (LOD) та межа кількісного визна-

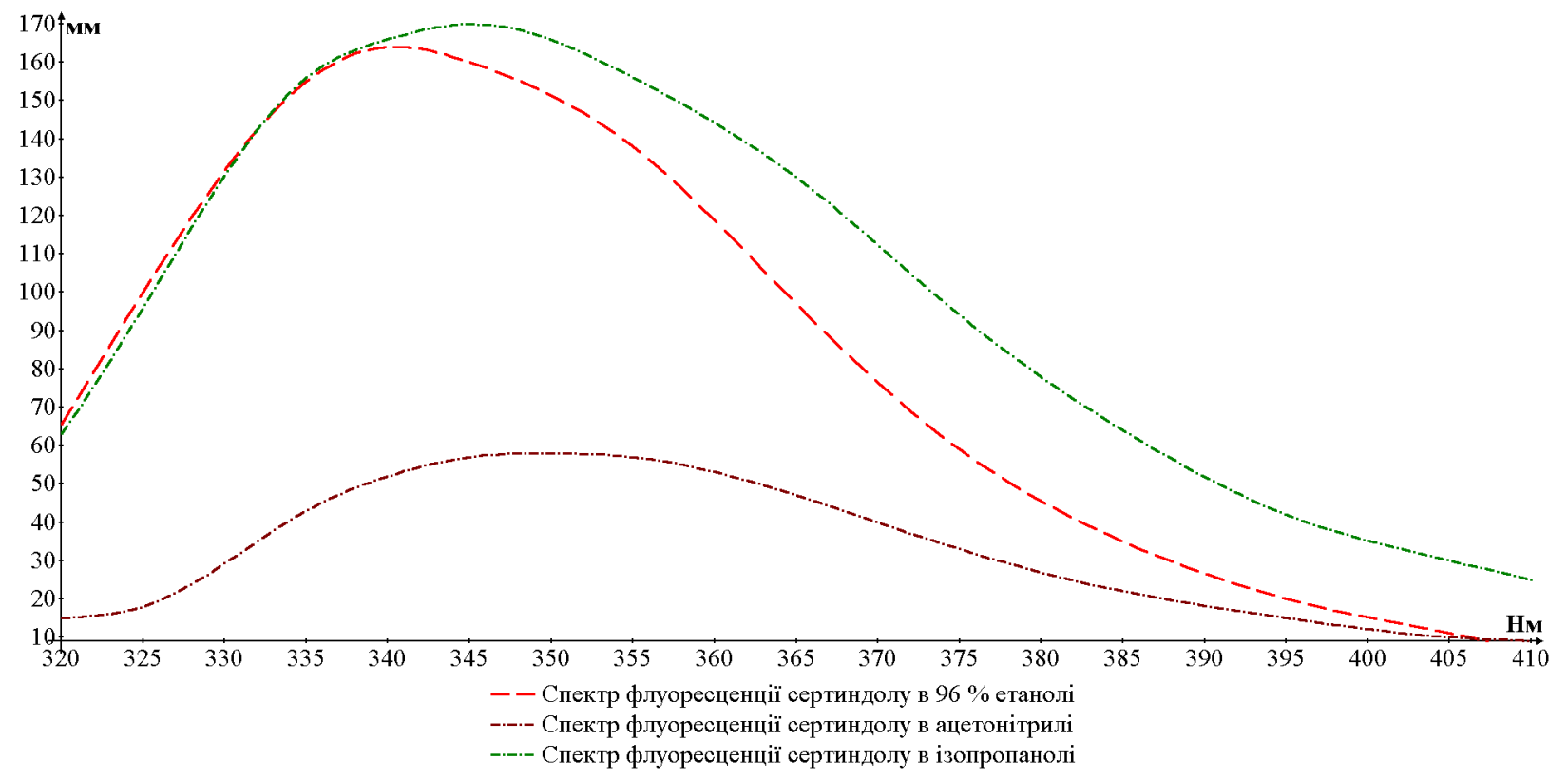

Рис. 1. Характер спектрів фрлуоресценції сертиндолу в 96 \% етанолі, ізопропанолі та ацетонітрилі.

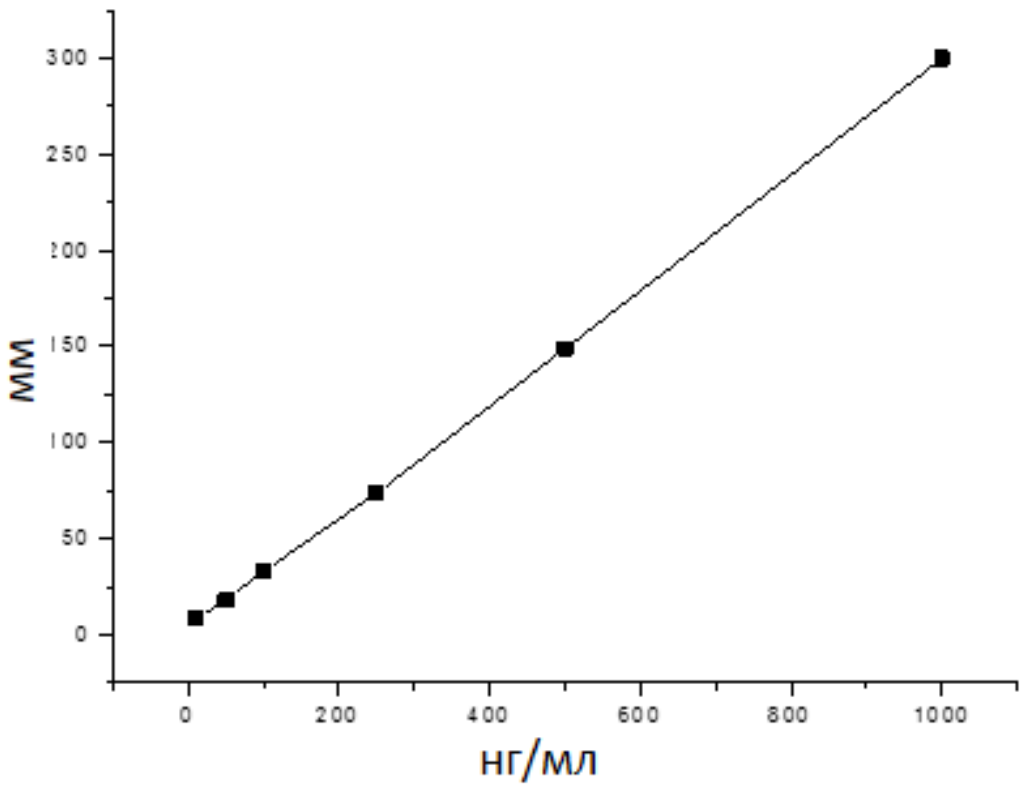

Рис. 2. Градуювальний графрік кількісного визначення сертиндолу методом фрлуориметрії.

ISSN 2312-0967. Pharmaceutical review. 2016. № 3 
чення (LOQ) сертиндолу в цьому розчині становлять 4 нг мл та 10 нг/мл відповідно.

Результати кількісного визначення сертиндолу в пробах крові методом фрлуориметрії наведено в таблиці 1.
Як видно з даних, представлених в таблиці 1, межа визначення сертиндолу в 1 мл крові методом фрлуоресцентної спектроскопії становить 12 нг в 1 мл проби.

Відносна похибка кількісного визначення сертиндолу в крові не перевищує 2,41 \%.

Таблиця 1. Результати визначення сертиндолу в крові методом фрлуориметрії

\begin{tabular}{|c|c|c|c|}
\hline \multirow{2}{*}{$\begin{array}{c}\text { Внесено сертиндолу (нг) } \\
\text { до 5 мл крові }\end{array}$} & \multicolumn{2}{|c|}{ Виділено препарату } & $\begin{array}{c}\text { Метрологічні характеристики } \\
\text { методу }\end{array}$ \\
\cline { 1 - 3 } & нг & 82,00 & $\overline{\mathrm{X}}_{=84,87}$ \\
\hline 50 & 41 & 83,20 & $\mathrm{SD}=2,05$ \\
\hline 250 & 208 & 84,40 & $\mathrm{~s}^{\bar{x}}=0,84$ \\
\hline 500 & 422 & 85,60 & $\Delta \mathrm{X}= \pm 2,05$ \\
\hline 1250 & 1070 & 86,68 & $\bar{X}_{ \pm} \bar{x}=84,87 \pm 2,05$ \\
\hline 2500 & 2167 & 83,20 & $\varepsilon=2,41 \%$ \\
\hline
\end{tabular}

Висновки. Вивчено ефективність ізолювання сертиндолу 3 модельних зразків крові. Розроблено умови кількісного визначення сертиндолу шляхом вимірювання його природної фрлуоресценції в полярних розчинниках.

Запропонований фрлуориметричний метод для визначення сертиндолу в крові має високу стабіль- ність та чутливість - дозволяє визначати мінімальні концентрації препарату. Дану методику можна використовувати для визначення терапевтичного та токсичного рівнів концентрацій сертиндолу в крові при проведенні лабораторних та токсикологічних досліджень.

\section{Список літератури}

1. Pae C. U. Sertindole: dilemmas for its use in clinical practice / C. U. Pae // Expert opinion on drug safetyю - 2013. - Vol. 12, №3. - P. 321-326.

2. Waldman W. Acute poisoning with sertindole - a case report / W. Waldman, K.Kaletha, J. Sein Anand // Przeglad Lekarski. - 2013. - Vol. 70, №8. - P. 669- 670.

3. Drug safety and efficacy evaluation of sertindole for schizophrenia. / E. Karamatskos, M. Lambert, C. Mulert [et al.] // Expert opinion on drug safety. - 2012. - Vol. 11, № 6. - P. 1047-1062.

4. Stability-Indicating Chromatographic Methods for the Determination of Sertindole / N. A. El-Ragehy, N. Y. Hassan,

M. Abdelkawy [et al.] // Journal of chromatographic science. - 2014. - Vol. 52. №6. - P. 559-565.

5. Determination of the concentration of sertindole in human plasma by RP-HPLC with UV detection / W. Z. Liu, Q. X. Chen, H. M. Shi [et al.] // Chinese Journal of Hospital Pharmacy. - 2010. - №18. - P. 19-22.

6. Micelle enhanced and native spectrofluorimetric methods for determination of sertindole using sodium dodecyl sulfate as sensitizing agent / A. M. El-Kosasy, L. A. Hussein, N. G. Sedki [et al.] // Spectrochimica Acta Part A: Molecular and Biomolecular Spectroscopy. - 2016. - №153. - P. 422-427.

\section{ОПРЕДЕЛЕНИЕ СЕРТИНДОЛА В КРОВИ МЕТОДОМ ФЛУОРЕСЦЕНТНОЙ СПЕКТРОСКОПИИ}

\section{С. И. Давыдович ${ }^{1}$, И. И. Галькевич ${ }^{1}$, О. В. Шамлян}

Львовский национальный медицинский университет имени Данила Галицкого ${ }^{1}$ Центральная научно-исследовательская лаборатория и лаборатория промышленной токсикологии ${ }^{2}$ Львов

Резюме: несмотря на прогресс в лечении психических заболеваний, лечение таким современными антипсихотическим средством, как сертиндол до сих пор ассоциируется с токсическими и летальными последствиями. Поэтому целью даной работы была разработка чувствительной методики определения сертиндола в крови используя фрлуоресцирующие свойства данного препарата. В 96 \% этаноле спектр фрлуоресценции сертиндола характеризуется возбуждением молекулы при 310 нм и эмиссией при 345 нм. В экстрактах из крови было определено до 87 \% сертиндола. Предел количественного определения сертиндола в крови составляет 12 нг/мл, при относительной ошибке - 2,41%.

Ключевые слова: сертиндол, кровь, фрлуоресценция, изолирование.

ISSN 2312-0967. Фармацевтичний часопис. 2016. № 3 


\title{
DETERMINATION OF SERTINDOLE IN BLOOD BY FLUORESCENCE SPECTROSCOPY
}

\section{S. I. Davydovych ${ }^{1}$, I. Y. Halkevych ${ }^{1}$, O. V. Shamlian}

\author{
${ }^{1}$ Danylo Halytskyi Lviv National Medical University \\ Central Research Laboratory and Laboratory of Industrial Toxiclogy, Lviv
}

Summary: fluorescence spectra of sertindole molecules in $96 \%$ ethanol is characterized by excitation at $310 \mathrm{~nm}$ and emission at $345 \mathrm{~nm}$. Relative error of sertindole quantification in $96 \%$ ethanol is $0.98 \%$. In extracts from the blood there were determined up to $87 \%$ sertindole. The limit of sertindole quantification in blood is $12 \mathrm{ng} / \mathrm{ml}$. Relative error of sertindole quantification in blood is $2.41 \%$. Conditions of sertindole isolation and identification in biological fluids on model mixes with blood are studied. Experimentally it was proved the feasibility of fluorometry developed techniques to quantify sertindole in extracts from biological fluids in forensic and toxicological investigations.

Key words: sertindole, blood, fluorescence, isolation. 